\title{
PENERAPAN COOPERATIVE INTEGRATED READING AND COMPOSITION (CIRC) UNTUK MENINGKATKAN PRESTASI BELAJAR BAHASA INDONESIA PADA SISWA KELAS XI.IPS.2 SMAN 4 MUARO JAMBI TAHUN PELAJARAN
} 2018-2019

\author{
PRISKA SIMBOLON \\ SMA Negeri 4 Muaro Jambi, Provinsi Jambi \\ Email : priskasimbolon86@gmail.com
}

\begin{abstract}
ABSTRAK
Penelitian ini bertujuan untuk mengetahui peningkatan prestasi belajar bahasa Indonesia siswa kelas XI.IPS.2 SMA Negeri 4 Muaro Jambi pada pokok bahasan menulis naskah drama melalui model pembelajaran Cooperative Integrated Reading and Composition (CIRC). Jenis penelitian ini adalah Penelitian Tindakan Kelas (PTK) yang dilaksanakan di kelas XI.IPS.2 SMA Negeri 4 Muaro Jambi yang berjumlah 29 orang siswa. Data hasil observasi dan tanggapan siswa dianalisis dengan menggunakan analisis persentase, sedangkan data hasil tes dianalisis menggunakan statistik deskriptif. Adapun hasil penelitian yang diperoleh menggambarkan hasil tes siswa mengalami peningkatan prestasi belajar setelah diberikan penerapan model pembelajaran Cooperative Integrated Reading and Composition (CIRC). pokok bahasan menulis naskah drama, siswa kelas XI.IPS.2 SMA Negeri 4 Muaro Jambi melalui penerapan model pembelajaran Cooperative Integrated Reading and Composition (CIRC)yang ditandai dengan tercapai ketuntasan belajar secara individu dan kelompok, yakni pada siklus I sebanyak 4 orang atau 13,8\% dan pada siklus II 29 orang atau 100\%. Hasil tersebut membuktikan bahwa penerapan pembelajaran Cooperative Integrated Reading and Composition (CIRC) dapat meningkatkan prestasi belajar bahasa Indonesia siswa kelas XI.IPS.2 SMA Negeri 4 Muaro Jambi.
\end{abstract}

Kata Kunci: Cooperative Integrated Reading and Composition (CIRC), prestasi belajar, Bahasa Indonesia.

\section{PENDAHULUAN}

Bahasa merupakan alat komunikasi bagi manusia. Tanpa bahasa manusia tidak dapat berkomunikasi di lingkungannya. Bahasa digunakan untuk mengungkapkan pikiran dan perasaan. Bahasa juga mencerminkan kepribadian seseorang. Setiap anggota masyarakat yang terlibat komunikasi selalu berusaha agar orang lain dapat memahami yang diungkapkan sehingga terjalin. Pada mata pelajaran Bahasa Indonesia, kemampuan berbahasa sangat penting untuk menumbuhkan dan mengembangkan siswa ke arah berbahasa secara kreatif. Salah satu sarana yang dapat mengembangkan kreativitas siswadalam berbahasa adalah dengan melalui tulisan. Keterampilan menulis merupakan sarana pengembangan keterampilan berbahasa Indonesia. (Yulismayanti, 2017). Pembelajaran menulis pada siswa SMA memberikan banyak manfaat, seperti mengembangkan kreativitas, menanamkan keberanian dan percaya diri, menata dan menjernihkan pikiran, cara berpikir, kecerdasan dan kepekaan emosi siswa.

Adapun belajar mengajar merupakan suatu sistem yang meliputi beberapa komponen seperti tujuan, bahan pelajaran, model, alat dan sumber evaluasi. Guru memiliki peranan penting dalam mengorganisasikan komponen-komponen dari sistem tersebut, untuk menciptakan lingkungan belajar yang kreatif sehingga tujuan dari pembelajaran dapat tercapai. Salah satu komponen yang sangat berpengaruh dalam proses belajar-mengajar adalah model mengajar.

Melihat kondisi realitas yang terjadi di SMA Negeri 4 Muaro Jambi, khususnya mata pelajaran bahasa Indonesia mengenai menulis naskah drama telah diajarkan oleh guru dengan berbagai model pembelajaran yang sifatnya dapat meningkatkan motivasi, minat, dan prestasi belajar siswa dalam pembelajaran. Model pembelajaran ini dikatakan belum efektif dalam proses pembelajaran, karena dilihat dari hasil belajar siswa belum memperlihatkan hasil yang 


\section{LANGUAGE : Jurnal Inovasi Pendidikan Bahasa dan Sastra Vol 1. No 1. Agustus 2021, e-ISSN : 2807-1670 | p-ISSN : 2807-2316}

maksimal. Hal ini tampak pada hasil pembelajaran pada semester sebelumnya menunjukkan bahwa nilai siswa masih sangat kurang. Data terakhir tahun pelajaran 2018/2019 jumlah seluruh siswa kelas XI SMA Negeri 4 Muaro Jambi sebanyak 315 dan nilai rata-rata masih rendah, yakni 64. Hal ini menunjukkan masih banyak siswa yang belum mampu mencapai standar yang telah ditetapkan yaitu mencapai nilai 75. Dengan demikian, banyak siswa yang dinyatakan belum tuntas. Pencapaian prestasi belajar Bahasa Indonesia yang optimal dalam proses belajar siswa dapat dipengaruhi oleh banyak faktor. Hal inilah yang mungkin menjadi penyebab kurangnya daya serap siswa dalam mencapai prestasi belajar. Dalam proses pembelajaran diperlukan adanya kemandirian belajar agar tercapai tujuan pembelajaran yang baik.

Syah (2011: 141) menjelaskan prestasi belajar adalah keberhasilan siswa mencapai tujuan yang telah ditentukan sesuai dengan program. Prestasi belajar yang dicapai siswa adalah sesuai kriteria yang telah di tetapkan prestasi belajar ini digunakan untuk menilai hasil yang di peroleh oleh siswa. Suryabrata dalam Intani (2018) menjelaskan prestasi adalah nilai perumusan terakhir yang dapat diberikaan oleh guru mengenai kemajuan/prestasi siswa selama masa tertentu. dari pendapat di atas dapat disimpulkan prestasi belajar adalah hasil usaha siswa yang dapat dicapai berupa penguasaan, pengetahuan, kemampuan, kebiasaan dan keterampilan serta sikap setelah mengikuti proses pembelajaran yang dapat dibuktikan dengan hasil tes. Oleh karena itu dibutuhkan model pembelajaran yang mampu melibatkan siswa secara penuh dalam pembelajaran agar siswa mampu memahami seluruh pembahasan dan tindakan yang akan dilakukan sehingga pembelajaran berpusat pada siswa. Salah satu model pembelajaran yang melibatkan siswa secara aktif adalah model Cooperative Learning.

Salah satu jenis pembelajaran yang menjadi pembelajaran berpusat pada siswa saat ini adalah Cooperative Learning.Cooperative Learning adalah suatu model belajar kelompok yang setiap anggota menyumbangkan informasi, pengalaman ide, sikap, pendapat, kemampuan dan keterampilan yang dimilikinya, untuk secara bersama-sama saling meningkatkan pemahaman seluruh anggota. Cooperative Learning memungkinkan setiap siswa memahami seluruh bagian pembahasan, tidak seperti pada kelompok belajar yang dikenal selama ini, yang menyebabkan hanya sebagian siswa memahami materi tertentu.

Ada banyak kelebihan yang bisa didapatkan oleh siswa apabila menerapkan pembelajaran kooperatif, antara lain melatih rasa peduli, perhatian dan kerelaan untuk berbagi, mendorong siswa untuk menjadi pembelajar yang mandiri, percaya diri, dan bertanggung jawab, meningkatkan kemampuan berpikir kritis dan meningkatkan rasa penghargaan terhadap orang lain, melatih kecerdasan emosional serta mengutamakan kepentingan kelompok dibandingkan kepentingan pribadi, mengasah kecerdasan interpersonal dan yang perlu dimiliki adalah bagaimana melatih kemampuan bekerja sama (team work) dengan teman kelompoknya sehingga menciptakan suasana belajar yang menyenangkan. Adapun kekurangan yang memungkinkan muncul dalam pembelajaran kooperatif adalah siswa yang lebih pintar akan merasa dirugikan apabila belum mengerti tujuan yang sesungguhnya dari proses ini, siswa akan merasa keberatan karna nilai yang diperoleh ditentukan oleh prestasi atau pencapaian kelompoknya serta hanya siswa yang pintar yang aktif saja yang menyumbangkan informasi kepada teman kelompoknya, sehingga prestasi itu bergantung pada pencapaian proses belajar yang dilakukan secara berkelompok.

Model Cooperative Learning adalah kegiatan belajar mengajar dalam kelompok kecil, siswa belajar dan bekerjasama untuk sampai pada pengalaman belajar yang optimal baik pengalaman individu maupun kelompok. Berbagai hasil penelitian menyimpulkan manfaat Cooperative Learning tidak hanya menghasilkan prestasi akademik yang lebih tinggi untuk seluruh siswa namun juga meningkatkan rasa percaya diri, kemampuan untuk melakukan hubungan sosial serta mampu mengembangkan saling kepercayaan sesamanya baik secara individu maupun kelompok, dan kemampuan saling membantu dan bekerjasama antar teman. Dan pula terhindar dari persaiangan antar individu, dengan kata lain tidak saling mengalahkan antar siswa. (Rofiq, 2010). Model pembelajaran kooperatif mengkondisikan siswa belajar bersama dalam kelompok-kelompok kecil saling membantu satu sama lain. Kelas disusun 


\section{LANGUAGE : Jurnal Inovasi Pendidikan Bahasa dan Sastra Vol 1. No 1. Agustus 2021, e-ISSN : 2807-1670 | p-ISSN : 2807-2316}

dalam kelompok yang terdiri dari 4 atau 5 siswa, dengan kemampuan yang heterogen. Hal ini bermanfaat untuk melatih siswa untuk menerima perbedaan pendapat dan bekerja dengan teman yang berbeda latar belakangnya. Siswa belum boleh mengakhiri diskusinya sebelum mereka yakin bahwa seluruh anggota timnya menyelesaikan seluruh tugas (Masjudin, 2017). Proses belajar mengajar dengan menggunakan model ini, para siswa yang memiliki tingkat akademik yang berbeda-beda diharapkan dapat mengemukakan permasalahan yang dihadapi dalam diskusi kelompok untuk dipecahkan bersama sementara tugas pengajar berperan sebagai fasilitator dan pembimbing.

Adapun Cooperative Integrated Reading and Composition (CIRC) adalah salah satu model cooperative learning yang bisa diterapkan dan dapat mengaktifkan siswa dalam belajar dengan teman sekelompoknya yang terdiri atas 4-5 siswa. Dalam kelompok ini sebaiknya ada siswa yang pandai, sedang atau lemah, dan masing-masing siswa merasa cocok satu sama lainnya. Dengan pembelajaran Cooperative Integrated Reading and Composition (CIRC) diharapkan siswa membangun kemampuan untuk membaca dan mampu mengerjakan soal-soal berbentuk wacana agar meningkatkan cara berfikir kritis, kreatif dan menumbuhkan rasa sosial yang tinggi pada saat pembelajaran di kelas (Syaputri, Djulia, 2018).

Model pembelajaran Cooperative Integrated Reading and Composition (CIRC) merupakan model pembelajaran terpadu menggabungkan kemampuan menulis dan membaca sehingga diharapkan dapat melatih siswa untuk bekerjasama dan memberikan tanggapan dan pendapat secara bebas (Heriawan, 2012:116).Hal ini sejalan dengan penjelasan dalam penelitian yang dilakukan oleh Jatmiko (2012) merupakan program pengajaran khusus yang dirancang untuk meningkatkan kinerja siswa dalam membaca dan menulis. Sehingga siswa mampu mengeluarkan ide-ide untuk memahami suatu konsep dan menyelesaikan tugas, sehingga membentuk pemahaman dan pengalaman belajar yang lama. Dalam penjelasan lain dikatakan bahwa model Pembelajaran Kooperatif Tipe CIRC singkatan dari Cooperative Integrated Reading and Compotition, termasuk salah satu model pembelajaran cooperative learning yang pada mulanya merupakan pengajaran kooperatif terpadu membaca dan menulis (Utami, Darsana, Suadnyana, 2014).CIRC ini merupakan model pembelajaran yang kooperatif dimana siswa akan di bentuk menjadi sebuah kelompok kecil yang akan bertanggung jawab terhadap tugas yang diperankannya. Dapat di simpulkan bahwa model pembelajaran CIRC merupakan model pembelajaran yang menekankan siswa untuk bekerja sama agar dapat mengerjakan dengan baik, efektif dan efisien dimana keberhasilan belajar diperoleh secara bersama-sama bukan semata-mata kemampuan individual (Hasriyanti, 2019). Keunggulan model pembelajaran CIRC menurut, Slavin dalam Miftahul (2015) menyebutkan kelebihan model pembelajaran CIRC sebagai berikut: (1) CIRC amat tepat untuk meningkatkan keterampilan siswa dalam menyelesaikan soal pemecahan masalah; (2)Dominasi guru dalam pembelajaran berkurang; (3) Siswa termotivasi pada hasil secara teliti, karena dalam kelompok; (4) Para siswa dapat memahami makna soal dan saling mengecek pekerjaannya; (5) Membantu siswa yang lemah. (6) Meningkatkan hasil belajar khususnya dalam menyelesaikan soal yang berbentuk pemecahan masalah.Faktor-faktor tersebut baik secara terpisah maupun secara bersama-sama memberikan kontribusi tertentu terhadap prestasi belajar peserta didik.

Berdasarkan hal tersebut, penulis mengkaji penerapan modelkooperatif sebagai upaya meningkatkan prestasi siswa di kelas XI.IPS 2 SMA Negeri 4 Muaro Jambi yang bertujuan untuk mengetahui peningkatan prestasi belajar bahasa Indonesia siswa kelas kelas XI.IPS.2 SMA Negeri 4 Muaro Jambi pada pokok bahasan menulis naskah drama melalui model pembelajaran kooperatif.

\section{MODEL PENELITIAN}

Penelitian ini merupakan Penelitian Tindakan Kelas (PTK) yang dilaksanakan pada bulan September sampai bulan Desember 2018 yang bertempat di SMA Negeri 4 Muaro Jambi. Subjek penelitian dalam penelitian ini adalah siswa kelas XI.IPS.2 SMA Negeri 4 Muaro Jambi semester gaanjil tahun pelajaran 2018/2019 yang berjumlah 29 orang. Penelitian ini 
menggunakan desain Penelitian Tindakan Kelas (class roam action researh) yang terdiri atas beberapa siklus tergantung ketercapaian tujuan penelitian pada siklus sebelumnya. Prosedur penelitian tindakan kelas yang dilakukan yaitu terdiri dari 4 komponen utama. Keempat komponen tersebut dapat dituliskan sebagai berikut: 1) Tahap perencanaan tindakan, 2) Tahap pelaksanaan kegiatan, 3) Tahap pelaksanaan evaluasi dan, 4) Tahap refleksi (Arikunto, Suharsini. 2003).

Teknik Pengumpulan Data yang digunakan dalam penelitian ini adalah tes, observasi, dan angket. Data hasil observasi dan tanggapan siswa dianalisis dengan menggunakan analisis persentase, sedangkan data hasil tes dianalisis menggunakan statistik deskriptif. Statistik deskriptif bertujuan untuk mendeskripsikan data yang diperoleh berupa skor ideal, skor tertinggi, skorterendah, dan rata-rata. Selanjutnya dilakukan pengelompokan secara pengkategorian yang terdiri atas: kategori sangat tinggi, sedang, rendah dan sangat rendah.

\section{HASIL DAN PEMBAHASAN}

\section{Data Prestasi Belajar Siswa Melalui Penerapan Model \\ Pembelajaran Cooperative Integrated Reading and Composition (CIRC)}

Tabel 1. Nilai Statistik Siklus I dan siklus II

\begin{tabular}{lcc}
\hline ProfilNilai & \multicolumn{2}{c}{ Nilaistatistik } \\
& Siklus I & SiklusII \\
\hline Jumlah sampel & 29 & 29 \\
Skor rata-ata & 56 & 80,4 \\
Skor tertinggi & 64 & 95 \\
Skor terendah & 40 & 64 \\
\hline
\end{tabular}

Nilai hasil tes siswa mengalami peningkatan setelah diberikan penerapan model pembelajaran Cooperative Integrated Reading and Composition (CIRC). Hal ini dapat dilihat dari perolehan nilai rata-rata dari 56 persen pada siklus satu meningkat menjadi 80,4 persen pada siklus II.

Nilai prestasi belajar bahasa Indonesia setelah penerapan model pembelajaran Cooperative Integrated Reading and Composition (CIRC) di kelompokkan dalam lima kategori, maka diperoleh distribusi frekuensi dan persentase nilai siklus I dan siklus II dapat dilihat pada tabel 2 .

Tabel 2. Frekuensi dan persentase nilai hasil belajar

\begin{tabular}{cclcccc}
\hline & & & \multicolumn{2}{c}{ Frekuensi } & \multicolumn{2}{c}{$\begin{array}{c}\text { Persentase } \\
(\%)\end{array}$} \\
No & Nilai & Kategori & Siklus & Siklus & Sikl & Siklus \\
& & & I & II & usI & II \\
\hline 1 & $0-34$ & Sangatrendah & - & - & 0 & 0 \\
2 & $35-54$ & Rendah & 11 & 0 & 37,9 & 0 \\
3 & $55-64$ & Sedang & 18 & 1 & 62,1 & 3,4 \\
4 & $65-84$ & Tinggi & 0 & 22 & 0 & 75,9 \\
5 & $85-100$ & Sangattinggi & 0 & 6 & 0 & 20,7 \\
\hline \multicolumn{3}{c}{ Jumlah } & 29 & 29 & 100 & 100 \\
\hline
\end{tabular}

Jika prestasi belajar siswa pada siklus I dan siklus II dianalisis, maka ketuntasan belajar siswa dapat dilihat pada tabel 3 berikut ini:

Tabel 3. Deskripsi ketuntasan belajar siswa pada siklus I dan siklus II

Interval Frekuensi Persentase(\%)


LANGUAGE : Jurnal Inovasi Pendidikan Bahasa dan Sastra

Vol 1. No 1. Agustus 2021, e-ISSN : 2807-1670 | p-ISSN : 2807-2316

\begin{tabular}{|c|c|c|c|c|c|c|}
\hline No & skor & Kategori & $\begin{array}{c}\text { Siklus } \\
\text { I }\end{array}$ & $\begin{array}{l}\text { Siklus } \\
\text { II }\end{array}$ & SiklusI & $\begin{array}{l}\text { Siklus } \\
\text { II }\end{array}$ \\
\hline 1 & $0-61$ & Tidak tuntas & 25 & 0 & 86,2 & 0 \\
\hline 2 & $62-100$ & Tuntas & 4 & 29 & 13,8 & 100 \\
\hline \multicolumn{3}{|c|}{ Jumlah } & 29 & 29 & 100 & 100 \\
\hline
\end{tabular}

\section{Data Hasil Observasi Aktivitas Belajar Siswa Selama Siklus I dan Siklus II}

Adapun hasil pengamatan terhadap aktivitas siswa kelas XI.IPS.2 SMA Negeri 4 Muaro Jambi yang menjadi subjek penelitian selama berlangsungnya proses belajar mengajar pada siklus I dan siklus II melalui penerapan model pembelajaran Cooperative Integrated Reading and Composition (CIRC) dapat dilihat pada tabel 4.

Tabel 4. Hasil observasi aktivitas belajar siswa selama siklus (\%)

\begin{tabular}{|c|c|c|c|}
\hline No & Deskriptif & $\begin{array}{l}\text { Siklus } \\
\text { (I) }\end{array}$ & $\begin{array}{l}\text { Siklus } \\
\text { (II) }\end{array}$ \\
\hline 1 & Jumlah siswa yang hadir pada saat pembelajaran & 85 & 87,5 \\
\hline 2 & $\begin{array}{l}\text { Jumlah siswa yang tidak memperhatikan pada saat materi } \\
\text { dijelaskan }\end{array}$ & 22,5 & 15 \\
\hline 3 & $\begin{array}{l}\text { Jumlah siswa yang bertanya pada saat } \\
\text { pembelajaran berlangsung }\end{array}$ & 17,5 & 27,5 \\
\hline 4 & $\begin{array}{l}\text { Jumlah siswa yang meminta untuk dijelaskan } \\
\text { Ulang suatu konsep dan contoh ekspresi muka dalam pementasan } \\
\text { drama }\end{array}$ & 12,5 & 7,5 \\
\hline 5 & 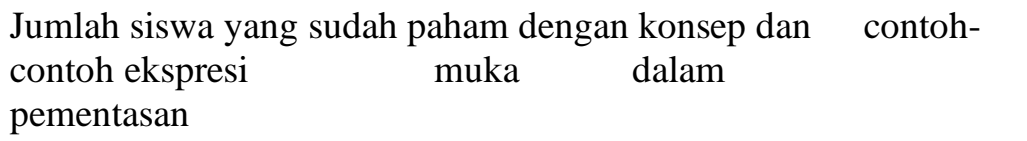 & 45 & 50 \\
\hline 6 & $\begin{array}{l}\text { Jumlah siswa yang aktif latihan pementasan } \\
\text { Drama }\end{array}$ & 22,5 & 35 \\
\hline 7 & Jumlah siswa yang aktif pada saat pementasan & 21,5 & 50 \\
\hline 8 & $\begin{array}{l}\text { Jumlah siswa yang masih memerlukan bimbingan } \\
\text { Dalam pementasan drama }\end{array}$ & 22,5 & 12,5 \\
\hline 9 & $\begin{array}{l}\text { Jumlah siswa yang sudah mampu memerankan } \\
\text { Salah satu tokoh dalam drama }\end{array}$ & 42,5 & 47,5 \\
\hline 10 & $\begin{array}{l}\text { Jumlah siswa yang } \\
\text { drama }\end{array}$ & 12,5 & 15 \\
\hline
\end{tabular}

Berdasarkan hasil observasi tersebut menggambarkan adanya peningkatan pada siklus II: a). Siswa dalam menyimak materi pelajaran serta keaktifan siswa dalam kelas mulai terbangun, terlihat dari jumlah siswa yang bertanya dan memberikan tanggapan mulai meningkat. b). Keberanian dan kesungguhan siswa menerima materi semakin baik. Hal ini terlihat dari jumlah siswa yang mengerjakan soal dipapan tulis dan aktif pada saat pembahasan soal semakin meningkat. c). Kegiatan siswa yang melakukan respon semakin berkurang. Hal ini terlihat dari jumlah siswa yang tidak memperhatikan pada saat pembelajaran berlangsung juga semakin berkurang. d). Ketuntasan kelas yang diperoleh yaitu $100 \%$ sesuai dengan indikator keberhasilan yang ditetapkan oleh sekolah SMA Negeri 4 Muaro Jambi. 


\section{Pembahasan}

Berdasarkan hasil yang diperoleh siswa pada setiap siklus terutama pada siklus II menggambarkan bahwa penerapan model Cooperative Integrated Reading and Composition (CIRC) pada pembelajaran bahasa Indonesia dapat menunjukkan respon yang positif dan keaktifan siswa karena siswa sudah mampu berinteraksi dengan siswa lain sehingga terbentuk hubungan yang bermakna. Hal ini sesuai dengan pernyataan Rusman (2011:203) yang menyatakan bahwa dalam pembelajaran kelompok akan tercipta sebuah interaksi yang lebih luas, yaitu interaksi dan komunikasi yang dilakukan antara guru dengan siswa, siswa dengan siswa, dan siswa dengan guru. Selain itu, selama penerapan pembelajaran Cooperative Integrated Reading and Composition (CIRC) perhatian dan aktivitas belajar siswa mengalami kemajuan, hal ini dapat dilihat dari persentase kehadiran siswa, siswa yang bertanya pada saat pembelajaran yang berlangsung, siswa yang tidak memperhatikan pada saat materi dijelaskan, siswa yang aktif pada saat pembahasan soal. Kemampuan siswa untuk memahami materi juga mengalami peningkatan. Namun, siswa yang aktif mengerjakan soal dipapan tulis masih kurang, hal ini disebabkan oleh rasa takut salah dan rasa percaya diri yang masih kurang untuk tampil di depan kelas.

Berdasarkan hasil pengamatan, dampak positif yang ditimbul setelah dilakukan tindakan di atas yaitu interaksi antara siswa tergolong baik. Karena hampir semua siswa berpartisipasi aktif menyelesaikan soal latihan. Keberanian siswa dalam mengerjakan soal di papan tulis, menanggapi jawaban siswa lain dan mengajukan pertanyaan semakin bertambah. Suasana belajar juga bersifat responsif dan menyenangkan.

Dalam penguasaan materi yang dibahas, mengalami peningkatan jika dibandingkan dengan siklus I. Hal ini terlihat dari persentase untuk kategori sangat rendah $0 \%$ dan rendah $0 \%$ sudah berkurang. Sedangkan untuk kategori sedang 0\%, tinggi 75,9\% dan sangat tinggi 20,7\%. Disamping Itu, skor rata-rata yang dicapai meningkat dari 56 menjadi 80,4 dan berada pada kategori tinggi. Demikian pula dengan ketuntasan belajar yang mencapai 85\%. Data inimenunjukkan bahwa rata-rata prestasi belajar dan daya serap siswa tergolong cukup. Pencapaian hasil tersebut sesuai dengan jalan pikiran yang yang diungkapkan oleh Johnson (2010:35) yang mengatakan bahwa pembelajaran adalah sebuah proses personal dan sosial yang akan membawa hasil jika setiap individu saling bekerjasama untuk membangun pemahaman dan pengetahuan bersama.

\section{KESIMPULAN}

Berdasarkan hasil penelitian dan pembahasan, maka dapat di simpulkan bahwa terjadi peningkatan prestasi belajar bahasa Indonesia pokok bahasan menulis naskah drama, siswa kelas XI.IPS.2 SMA Negeri 4 Muaro Jambi melalui penerapan model pembelajaran Cooperative Integrated Reading and Composition (CIRC) yang ditandai dengan tercapai ketuntasan belajar secara individu dan kelompok, yakni pada siklus I sebanyak 4 orang atau 13,8\% dan pada siklus II 29 orang atau $100 \%$.

Penerapan model pembelajaran Cooperative Integrated Reading and Composition (CIRC) lebih meningkat dari siklus I setelah dilakukan tindakan berikut: a). Menugaskan kepada siswa untuk membaca sebelumnya literatur yang berhubungan dengan materi. b). Memberikan konsep materi dengan menggunakan model ceramah dan tanya jawab kemudian dilanjutkan dengan memberikan contoh soal. c). Dalam menyelesaikan soal-soal latihan, siswa dibagi menjadi 8 kelompok diskusi yang terdiri dari 5 orang siswa tiap kelompok. d). Menugaskan kepada siswa agar anggota kelompok secara bergantian mewakili kelompoknya mengerjakan latihan di papan tulis. e). Memberikan pujian dan memotivasi siswa agar lebih percaya diri dalam menyelesaikan soal-soal latihan. f) Membahas soal yang dianggap sulit secara klasikal selama 15 menit. g). Siswa menyimpulkan materi yang telah mereka pelajari.

Penerapan model pembelajaran Cooperative Integrated Reading and Composition (CIRC) dalam pembelajaran bahasa Indonesia dapat meningkatkan motivasi dan aktivitas siswa dalam proses belajar mengajar, terlihat dari kehadiran siswa dalam mengikuti pembelajaran, 
jumlah siswa yang mengerjakan soal di papan tulis dan jumlah siswa yang menanggapi jawaban siswa lain.

\section{DAFTAR PUSTAKA}

Hasriyanti, H. (2019). Pengaruh Model Pembelajaran Cooperative Integrated Reading and Composition (Circ) Terhadap Hasil Belajar Siswa Sekolah Menengah Atas. LaGeografia, 18(1), 36-42.

Heriawan, Adang. (2012). Metodologi Pembelajaran Kajian Teoritis Praktis. Banten: LP3G.

Intani, C. P., \& Ifdil, I. (2018). Hubungan kontrol diri dengan prestasi belajar siswa. Jurnal EDUCATIO: Jurnal Pendidikan Indonesia, 4(2), 65-70.

Jatmiko, A. (2012). Penerapan Model Pembelajaran Kooperatif Tipe CIRC (Cooperative Integrated Reading and Composition) Disertai Media Komik Biologi untuk Meningkatkan Minat Belajar Siswa dalam Pelajaran Biologi pada Siswa Kelas VII-A SMP Negeri 14 Surakarta Tahun Pelajaran 2.

Masjudin, M. (2017). Pembelajaran kooperatif investigatif untuk meningkatkan pemahaman siswa materi barisan dan deret. JEMS: Jurnal Edukasi Matematika dan Sains, 4(2), 7684.

Miftahul Huda. (2015). Cooperative Learning Metode, Teknik, Struktur Dan Model Penerapan. Pustaka Pelajar. Yogyakarta.

Rofiq, M. N. (2010). Pembelajaran kooperatif (cooperative learning) dalam pengajaran pendidikan agama Islam. Jurnal Falasifa, 1(1), 1-14.

Suharsimi Arikunto. (2003). Dasar-Dasar Evaluasi Pendidikan. Jakarta: BumiAksara.

Syah, M. (2011). Psikologi Remaja. Yogyakarta: PT Tiara Wacana

Syaputri, C. N., \& Djulia, E. (2018). Pengaruh model CIRC (cooperative integrated reading and composition) dengan menggunakan peta konsep terhadap hasil belajar siswa pada materi jaringan tumbuhan di kelas XI IPA SMA Muhammadiyah 1 Medan. Jurnal Pelita Pendidikan, 6(1).

Utami, K. C. P., Darsana, I. W., \& Suadnyana, I. N. (2014). Pengaruh model pembelajaran cooperative integrated reading and composition terhadap hasil belajar IPA siswa kelas V. Mimbar PGSD Undiksha, 2(1).

Yulismayanti, Y. (2017). Keefektifan Strategi Cooperative Integrated Reading and Composition (CIRC) dalam Pembelajaran Menulis Naskah Drama pada Siswa Kelas X SMA Negeri 1 Bua Ponrang Kabupaten Luwu (Doctoral dissertation, UNIVERSITAS NEGERI MAKASSAR). 